\title{
Lexical Variation on Students' Daily Conversation at Campus by First Year Students of English Department FKIP HKBP Nommensen University
}

\author{
Rudiarman Purba \\ Faculty of English Education, University of HKBP Nommensen Pematangsiantar
}

\begin{abstract}
This articles deals with the finding of lexical variation in campus daily communication among friends on the first year students of English Department FKIP HKBP Nommensen University Pematangsiantar. This study adopted a qualitative case study approach. The question formulated by the writer is also registered as the problem of this study that is what lexical variation are used by the students in campus daily communication among friends on the first year students of English Department FKIP HKBP Nommensen University Pematangsiantar and what factors do influence it. In this study, the first year students of English Department FKIP HKBP Nommensen University Pematangsiantar are taken as the subject. So the objects are the lexical variations that are used in the students' conversation. Data collection was done through recording the student's daily conversation at campus. Four goups of students' conversation were analyzed in this research. In order to understand the student' lexical variation, sociolinguistics factors were investigated. Finally, the findings show the dominant sociolinguistics factors that influence the students' lexical variation is the language function which is used by the students namely informal language function.
\end{abstract}

Keywords: Lexical Variation, Sociolinguistics

\section{INTRODUCTION}

This research is the study on the lexical variation in campus daily communication among friends on the first year students of English Department FKIP HKBP Nommensen University Pematangsiantar. The Purpose of the current paper is to find out the lexical variation in campus daily communication among friends on the first year students of English Department FKIP HKBP Nommensen University Pematangsiantar and the factors influence it.The students came from many places around Pematangsiantar Town and Simalungun Regency even out of North Sumatera Province. They are chosen by the writer because the students can be the representative of students of English department of Teachers Training Faculty problem in case of anxiety in speaking English.

There are some reasons why this research is necessary to be done. First is the need of documentation for English department of Teachers Training Faculty HKBP Nommensen University Pematangsiantar. This documentation can be necessary for the needs practical and scientific uses in the next time. The second is to investigate the the lexical variation in campus daily communication among friends on the first year students of English Department FKIP HKBP Nommensen University Pematangsiantar and the factors influence it.

The findings of preliminary research for the sake of this study shows that lexical variation that are mostly used by the students in their daily campus communication among friend influenced by the factors as proposed by Wardhaugh (1972:188) namely: age, sex and occupation, function and regional variation.

At the end, based on the core theory of language variation, this article also proposed some strategies to solve the problem as Wardhaugh (1972) proposed in his previous findings.

To analyze the lexical variation in campus daily communication among friends on the first year students of English Department FKIP HKBP Nommensen University Pematangsiantar, the writer would like formulate the research problems by the following questions:

1. What are the lexical variation which are used by the first year students of English Department FKIP HKBP Nommensen University Pematangsiantar in their campus daily communication among friends?

2. What factors do influence the lexical variation of the students?

To answer the problem above, the writer tries to learn some literature related to the lexical variation and the factors influence it.

\subsection{Sociolinguistics}

\section{THEORETICAL REVIEW}

Sociolinguistics is a branch of linguistic which studies language variation and it's relation with social variable. As a branch of sociolinguistics, its connect with varied linguistics relations of socio cultural meaning 
which in a sense are both familiar and unfamiliar, the currency of everyday social interaction which are nevertheless relative to particular cultures such as societies, social groups, speech communication, language, dialect varieties, and style.

\subsubsection{Language Variation}

Linguistics has tended to disregard such variation in favor of linguistic models that stress unvarying systems and regularity. For example, some have concerned themselves with describing the speech of only one speaker, concentrating on his speech, or idiolect, and disregarding certain stylistic variation that occur even in such a sample. Others, particularly Tagger and Smith, have attempted to describe an overall system for a language from which individuals select a system.

An overall system does allow for variation in language, but only within a super system. Even in historical work, the comparative method of reconstruction and the family-tree model of genetic relationship work best when we disregard most kind of variation (Wardhaugh, 1972:188).

Although we have tended to ignore linguistic variation because of the need to develop models to account for what is general and universal in language rather than for what is individual and idiosyncratic, a commonsense view of "facts" tells us that considerable variation does occur within language. Speaker of a language speak is differently. There are good speaker of language such as English. There are intelligible see in many different ways.

According to Hymes (1974:206), competence as a personal ability not just grammatical knowledge, systematic potential of grammar, super organic property of society, or indeed, irrelevant to persons any other way. It is we have been more vitally concerned with trying to clarify the nature of language itself than making what could easily become unsystematic observation about surrounding phenomena. Linguistic have not completely ignored variation however and it is the purpose of this chapter to indicate some way in linguistic variation has been examined in a spirit motivated by the kind of scientific inquiry described in this chapter.

According to Wardhaugh (1972), there are 3 types of variation, they are: Phonological Variation, Lexical Variation, and Morphonological and syntactical Variation.

\subsubsection{Phonological Variation}

In phonology, linguistic have investigated such matter as the inventory of vowels and consonant of a particular region and the phonetic contrast the exits. In examining regional dialect, we try to determine the phonetic values of the vowel in such words as house, tide, noise, that is, those vowels that usually pronounced as diphthongs in must variation of English but which may have very different phonetic realization of the diphthongs. In some dialect to these words such as beat, bait, and boat also show interesting variation from dialect to dialect. Certain contrast may be present or lacking, particularly in combination with certain phonemes for example: /r/ or nasal phoneme.

\subsubsection{Lexical Variation}

All language change over time and vary according to place and social setting. The lexical variation in speaking influenced by some factor, such as: age, level of the education, and also linguistic competence. Lexical variation in speaking can be categorized into two main concepts. They are: formal and informal. The relations between concepts and the words which conventionally refer to those concepts is arbitrary and so either can vary or change fairly free though time and across space. According to Wardaugh (1972:192) different word may through time, evolve so as to be associated with different concepts. Honorific forms are also the marker of lexical variation. Particles are also the markers in lexical variation. Older speaker tend to communicated with the sense of politeness. When speakers speak impolitely, it is assumed that he/she is fewer components toward language and culture. Style can also show the lexical variation. If the situation is formal, the language that is used will be informal as well. It can be seen as Megawati as the ex president of Indonesia, when she delivered a formal speech in the front of Her party people, she always use 'Wong cilik' as his style to say masyarakat $\mathrm{kecil} / \mathrm{miskin}$ (poor man/family) And if the situation is not formal, the language that is used will be informal for instance in daily conversation (informal situation) youth style to say 'sayang' a man/woman calls his/her couple by saying 'honey'. The use of 'perhaps' or 'maybe' is a lexical variation differences in vocabulary. It certain locates the speaker somewhere in an area centre on pennies. The popular image of dialect speech tends to focus almost exclusively on dialect vocabulary and although there was at one time greater regional variation in vocabulary, there remains a great deal of lexical diversity.

Old speaker always practice the sense of formality. Young speakers always practice the sense of formality. On the other hand, styles are also a part of lexical variation. Sound and lexical variation were approached from sociolinguistic perspective; where by values of variables are correlated with specific social factors. 


\subsubsection{Morphological and Syntactical variation}

Syntactic different are apparently less tolerated than phonological differences among educated speakers of a language, therefore, such as speakers tend to eliminate them. These stigmatizes differences are regarded as non standard by linguistic nonstandard being no pejorative equivalent of the more usual designation, substandard (Wardaugh, 1972:194). The example of consonant cluster reduction given earlier also concerns morphological variation because the final consonant deleted is often a past-tense morpheme. Morphological and syntactic variation in ASL has not yet been extensively explored.

\subsection{Some Varieties of Language}

According to Wardhaugh (1972:188), there are many variation of language used by a group of people like age, sex and occupation, function and regional variation.

\subsubsection{By Age}

Of course other kinds of variation of dialect variation occur, and linguistic have shown an interest in some of these varieties. For example: language varieties according to the age of the person using it. It varies in this way because language must be learned and there appear to be stages through which individual progress of language acquisition. However, six year old children some have gone through most of these tags.

We all recognize that old people speak differently from young people and that linguistic generation gaps exits likewise, accepted patterns exits for communicating between and within the generations: old people to young, young to old, fathers to young children, young children to fathers, adolescents to their peers, and soon. Consequently, variation by age is one kind of linguistic phenomenon we can study and about which we can ask a variety of linguistic, psychological, and sociolinguistic questions (Wardhaugh, 1972:189)

\subsubsection{By Sex and Occupation}

Language also varies according to sex and occupation. The language of men differences substantly from that of women. Men do not usually use expressions such as darling, and women tend no to use profanity as extensively as men. Likewise, the one a today! And expression reserved complementing women. The occupation of person causes his language to vary, particularly in the use he of the he makes of technical terms, that is, in the use he makes of the jargon of his vocation, soldiers, dentists, mechanics, yachtsmen and skiers all have their particular special vocabulary is not shared by all. Although we can relate certain kinds of jargon to levels of education and professional training, we must also note that all occupations employ some jargon, even those criminals underworld. There may well be a more highly developed use of jargon in occupation the rewire considerable educations, in which world, and the concepts they express, are manipulated rather than objects. For the example: in the legal and teaching profession and in the world of finance (Warldhaugh, 1972:189).

\subsubsection{By Function}

Still other kinds of variation related to the function. There are both formal and informal styles of speaking and writing. Writing also tends to be more formal than speaking in the sense in more conscious manipulations of vocabulary and syntax takes a place. The most informal styles of speaking are often unjustly condemned, for very few word used to describe slang are anything other than pejorative. Slang, with is clipped and shortened forms, its novel uses and communications of words, and its exotic quicksilver display of language. It is a universal linguistic phenomenon. Slang is easiest to study than citizens, because it is very transience does not leave behind in the language the kind of evidence linguist prefer to study. Discussion of slang tend to bring out expressions of dismay and condemnation from those who misunderstand its natural function as the exuberant wordplay of a group often used to achieve some kind of group identity. Slang in particular and linguistic usage in general had been studied terms of cultural associations and functional uses. Yet the educated public has shown little acceptance of the few objective statements that can be made about the varieties of usage that occur in a language like English (Wardhaugh, 1972:190).

\subsubsection{Regional Variation}

The kind of variation that has most interested linguistic is dialect variation such as, interest result in part from connection between modern linguistics and older philological studies in which language were seen as continually fragmenting through dialect variation. The processed to evaluation of new languages. Consequently, linguistic have study dialects in relation to their geographic distribution, since they recognize that people in one location often speak a language differently again. In recent years a new dimension has been added to dialect studies party as a result of growth of sociology and the development of refined techniques for sampling large population in social dialects. The concerns of the rest of this chapter than is with these two aspects of language variation regional dialect and social dialect (Wardhaugh, 1972:190). 


\subsubsection{Cultural Aspect}

Culture guides the behavior of people in a community and is incubated in family live in governs our behavior in groups, make us sensitive to matter of status, and helps us know what other expect of us and what will happen if we do not like their expectations. Culture helps us know how far we can go us individuals and what our responsibility is to the group. Different cultures are the underlying structure which makes round community round and community square.

Culture also might be defined as the ideas, custom, skill, art, and tools which characterize a given group of people in a given period of time. But culture is mare than the sum of its parts. It is the system of integrated patterns. Most of which govern human behavior just as surely as the manipulated strings of a puppet control its motion.Nevertheless, such as pattern of living have in the view of some anthropologist universal. Characteristic of cultural pattern of behavior:

1. They originate in the human mind

2. They facilitate human and environmental interaction

3. They satisfy basic human needs

4. They are cumulative and just to change internal

5. They tend to form a consistent structured

6. They are learned and shared by all the member of a society

7. They are transmitted to new generations.

On the other hand, culture is a series of habits shared by member of a group living and geographic area, learned but biologically conditional, such as means of communication (language being the basic of them all), social relations at different levels, the variation activities of daily life, the product of that group and how they are utilized the peculiar manifestations of both individual and national personalities, and their ideas concerning of their existence and their follow people (Tampubolon, 2005: 89).

\section{RESEARCH METHODOLOGY}

This research used qualitative research method. The writer uses descriptive linguistic approach. It has aim to find out the lexical variation in the speaking which is used by the students in their daily campus communication. Patton (2002:4) stated that Qualitative research is characterized by its aims, which relate to understanding some aspect of social life, and its methods which (in general) generate words, rather than numbers, as data for analysis. Furthermore, Arikunto (2006:234) in Hatta (2007:5) stated that in presenting the data, descriptive analysis method is not generally directed toward hypothesis testing, but only to describe the existing phenomena and current condition without being influenced by the investigator.

To analyze language variation, the approach focuses on ethnographic language and discourse analysis in term of ethnographic language the data is analyzed in contextual communication. Discourse analysis demands the speaker negotiates with other speakers or listener. Sociolinguistic analysis studies about the aspect of language social situation especially the variation that discovered in language that interlace to social factor. So, in descriptive linguistic methodology, the language problem will be a resource to indicate the data. This study tries to look for system of language variation and the aspect of it.

\subsection{Subject of the Research}

The subject of research is the First Year students of English Department of Teacher Training and Education Faculty HKBP Nommensen University. The writer concentrated most on the students' performance in lexical variation in speaking among friends in their daily campus communication.

\subsection{Object of the Research}

The object the research is language variation in the difference of lexical form which is used by the First Year Students of English Department of Teacher Training and Education Faculty HKBP Nommensen University in speaking among friends in their daily campus communication.

\subsection{Instrument of the Research}

Because this research is intended to analyze the student's language variety in speaking among friends in their daily campus communication, the writer will use a mobile phone recorder as the instrument to record collecting the data.

\subsection{Technique of Collecting Data}

The writer use the technique in collecting data by observation and recording and the writer ask a student to put the mobile phone recorder on his/her pockets and record the natural conversation of his friends (The speakers do not realize that they are recorded). Observation will be by hearing, recording, such as: topic, the situation, place, manner, and person to when the students talking. This technique is done directly so that data 
will be collected accurately and directly. The writer will do some observation which is done by some steps as follows:

1. Recording students' speaking

2. Transcript the recorded conversation

3. Translate the transcription of the conversation into English language.

\subsection{Technique of Analyzing Data}

In analyzing the data, the writer analyze the lexical variation it selves. The data will be analyzed on the theory of Hymes (1974:55).

In this research, the writer analyzes the data by using steps as follows:

1. Translates the transcription of students' utterances (responses) into English language.

2. Identify the lexical variety in the students' conversation.

3. Classify the lexical variations

4. Interpret the factors influence language variation

\subsection{Data Analysis}

\section{DATA ANALYSIS, FINDINGS AND DISCUSSION}

\section{Data 1:}

Paian and Hendry are talking about manythigs, they are asking and giving information about canteen, class and food. They are close friend in the same level of first semester in the diffrent group of English department FKIP UHN Pematangsiantar. The conversation was done at 10.00-10.20 am on Saturday 06 February 2016 under the leafy trees

Paian:Dimana kantin di kampus ini ? (where is the canteen of this campus?)

Hendry:Disana , dibelakang menza . ada dibelakang menza , ada dibelakang ? (there, behind the menza. Behind the menza, there in the back side...?)

Paian:Dimana? (where?)

Hendry:Itu yang ruangan besar (there, the big rnom?

Paian:Aula? (hall?) 22

Hendry:Oh iya , terus dibelakang sma. (oh ya, go a head to the back of the the senior high school building)

Paian:Enak gak makanan disitu ? (How is the food there, diligious?)

Hendry:Yang dimana? (which one?)

Paian:Kantin belakang menza itu (the canteen behind the menza)

Hendry:Enak $\underline{\text { tapi }}$ mahal, nasinya $\underline{\text { aja }} 6$ ribu atau 8 ribu (tasty, but expensive, only rice six thousand or eight thousand?

Paian:Pakek teh manis berarti 10? (With sweet tea it would be ten thousand?)

Hendry: $\underline{G a k} \underline{t a u}$ lagilah berapa . Ikannya lagi ,sayurnya lagi ( I don't know how much the price will be anymore, increasing the fish, the vegetables)

Paian:Besok kau masih masuk ? (do you still have a class tomorrow?)

Hendry:Besok masuk (yes i do, i have a class tomorrow)

Paian:Masukya? (so, you have class?)

Hendry:Iyalah anak rajin ha ha (ya, diligent student ha..ha...)

Paian:Sok rajin kau di kampus ini , dengan sir apa kau besok masuk? (How diligent you are in this campus, who is your lecturer tomorrow?)

Hendry:Sir Partohap Sihombing (Sir PartohapSihombing)

Paian:Partohap Sihombing ? samalah berarti iya , tapi menurutmu kayak manalah bapak itu ?(Partohap

sihombing? We are the same, but according to you, what do you think about him ?)

Hendry:Bapak itu gimanaya ? enaknya itu dewasa lagi (how is the lecturer? He is good and adult)

Paian:Enaklah yaa palagi pembicaraannya mantap. Anak muda ,aku kalau belajar sama bapak itu gak ngantuk aku .kalau sudah ngantuk mantap $\underline{\text { kali }}$ dia bikin pembicaraan anak muda. (Nice, he is a nice lecture, especially his adult speaking. Young man. If he teaches us, i will never to be sleepy, and if he feels that the students geting boring or sleepy, he directly speak about adult material)

Hendry :Apalagi kalau sudah dibawa setiap hari pembicaraan anak muda. (Moreover if he talk about youngster conversation every meeting)

Paian:Tapikan kemaren waktu kami ngantar buku ketempat dia , kau bayangi kan diajak kita manggang manggang. (but, yesterday when we delivered the book to his place, we are invited roasting by him.)

Hendry :Aku kalau gak diajak gak mau aku. (if I was not invited, I will not want.)

Paian:Diajaknya kita 1 grup , kan dibilangnya dia paling suka grup kita kemaren apalagi katanya komisarisnya itu kan hahaha. (He persuade our group, he said that he like our group most yesterday, moreover the chairperson right ..ha..ha..ha..) 
Lexical Variation on Students' Daily Conversation at Campus by First Year Students of English Department

Hendry :Aku kalau diajak tapi kalau bayar gak samaku itu, harus gratisnya. (if he invite me and i must pay, i will not joit it. For me, it should be free)

Paian :Ya memang gratis kita, dana dari bapak itu nanti. (Yes indeed, its free for us, the funds from the him later)

Hendry :Baik bapak itu ya (he is kind, right)

Paian :Baik kali pun, hari sabtu sir Rudiarman masuk sama kalian? (really kind, Do you have class of sir Rudiarman on Saturday?)

Hendry :Sabtu gak, jumatnya kami masuk. ( not Saturday, but Friday.)

Paian :Jumat kalian? Kayak mana udaku itu ?aku kan purba dia purba, kayak mana uda ku itu enaknya ngajarnya?(you're Friday? How is my father's brother? I'm purba, how is my father's brother, does he teach enjoyable?)

Hendry : Kayak manalah sama-sama purba biasanya itu , purba ini kan pura-pura baik nya ini (nothing to say, they are the same Purba, that's usual, actually purba is ostensibly kind)

Paian :Bukan $\underline{\text { kayak }}$ gitu, kalian salah. Sudah diubah kepanjangan purba itu, purba itu menjadi kalau untuk yang cowok purba itu putra bangsa kalok yang putri itu putri bangsa .jadi kami itu purba itu sebenarnya kamilah calon-calon pembangun bangsa ini. Jadi kau salahdisitu. (Not like that, you are wrong. It's already changed becomes if he is son, Purba will be price of the nation andfor the woman will be the princess of the nation, so actually we are Purba, the candidate of this nation builder.)

Hendry :Oh...ha...ha... Ya $\underline{\text { udalah }}$ ya pai pulang lah $\underline{\boldsymbol{d u l u}}$ aku ya.(Oh haha. Well I want go home)

Paian :Eh cepat kali, mau kemana kau, gak jadi kekantin kita ?(Eh, why in hurry, where are you going?

Don't we go to canteen?

Hendry :Mau ngerjai depot aku. ( I want to do depot's home assignment.)

Paian :Depot? kan jam 3 nya. ( Depot? It's not at three?)

Hendry : $\underline{\boldsymbol{U d a h}}$ jam berapa sekarang? (What time is it now?)

Paian :Okelah, dahhh. (It's ok, bye.)

Analysis Data 1:

In the conversation above, we can find 15 Lexical variations they are: gak, tapi, aja, pakek, gak tau, kayak, palagi, kali, bikin, bayangi, gak samaku, udahlah, dulu, and udah.

There are fifteen lexical variation used by the students in communication among friends in data 1 and clasified into formal and informal lexical variation, they are:

\begin{tabular}{llll}
\hline No & & \multicolumn{1}{c}{ Informal } & \multicolumn{1}{c}{ Formal } \\
\hline 1 & - & Gak & - Tidak \\
2 & - & Tapi & - Tetapi \\
3 & - & Aja & - Saja \\
4 & - & Pakek & - Pakai \\
5 & - & Gak tau & - Tidak tahu \\
6 & - Sir & - Bapak \\
7 & - Kayak & - Seperti \\
8 & - Palagi & - Apalagi \\
9 & - Kali & - Sangat \\
10 & - Bikin & - Membuat \\
11 & - Bayangi & - Bayangkan \\
12 & - Gak samaku & - Tidak sama aku \\
13 & - Udahlah & - Sudahlah \\
14 & - Dulu & - Terlebih dahulu \\
15 & - Udah & - Sudah \\
\hline
\end{tabular}

The factors that influence the lexical variation in the conversation are Function (Informal language) like when the students to say tidak (no) they just say gak or nggak (the informal youth language to say no).

\section{Data 2:}

A conversation among studenst about examination, they are Arfandi, Ferry, Chandra, Dodi, and Edoward talking after examination and clarify about misunderstanding in helping their friend to answer the examination question. They talked in the front of the classroom at 10.00-10.15 am on Wednesday 3 February 2016. They are classmate who has just finish doing a final test of their subject. 
Arfandi : Orang ini payah $\underline{\text { kali }}$, minta $\underline{\mathbf{d u l u}}$ jawabanmu, payah $\underline{\mathbf{k a l i}} \underline{\mathbf{n g a s i h}}$. Coba di ajak ke parapat, langsung mau. ( You are so thingi, just give me you answer, you are so hard to give, if i ask you go to Parapat, you directly say yes. )

Ferry : Hahaha.. Jangan tanyakan itu kepada mereka. Kalau tentang liburan, mereka pasti langsung mau. ( Hahaha.. don't ask about it to them, talk about holiday, they want it directly. )

Chandra: Hahaha nengok situasi juga lah mau ngasih jawaban. Kau tengok lah pengawasnya tadi. ( Ha..ha..ha.. you have to see the situation if you want to give the answer. You had seen the supervisor just now. )

Dodi : Kau pun $\underline{\boldsymbol{u d a h}} \underline{\boldsymbol{k} \boldsymbol{u}} \underline{\boldsymbol{k a s i h}}$, tapi gak mau kau tengok. ( you are also wrong, when i give you the answer but you didn't looked at me )

Arfandi : Datang lagi abang ini, $\underline{\text { awak }} \underline{\text { nanya }}$, malah yang lain dijawab dia. ( and you brother, I ask to you something, but you answer another, not me. )

Edoward: Asal ujian lah, tambah musuh $\underline{\text { awak }}$. ( every examination moment, enemy get increase. )

Chandra: Pinjam dulu motormu, mau kedepan kami. ( Can I borrow your motorcycle ? We want to the front. ) Arfandi : Ini bisa kau pinjam, jawabanmu gak bisa kuminta. ( you can borrow my motorcycle, but you can not give me your answer. )

Edoward: Coba liat soalnya sini, oh gampang nya ini, Cuma mencocokkan aja nya ini. ( Can I see the questions ? Ohh it's not hard. Only matching pair)

All : Hahaha.. Semua gampang nya sama mu. ( Hahaha all for you are so easy friend. )

Arfandi : Besok ujian apa kita ? (what is our examination subject tomorrow ?)

All : Agama. (Religion )

Arfandi : $\underline{\text { Tengok }}$ kalian lah besok ya, gak abang kasih kalian. ( You will see tomorrow, I will not give you the answer. )

All : Hahaha baiklah baiklah ( Hahaha.. allright...allright )

\section{Analysis data 2:}

In the conversation above, we can find 14 Lexical variations they are payah, kali, dulu, ngasih, nengok, nengok, udah, kukasih, gak, awak, nanya, motormu, aja, and samamu.

The fourteen lexical variation used by the students in communication among friends in data 2 and clasified into formal and informal lexical variation, they are:

\begin{tabular}{|c|c|c|}
\hline No & Informal & Formal \\
\hline 1 & - Payah & - Sulit \\
\hline 2 & - Kali & - Sangat \\
\hline 3 & _ Dulu & - Terlebih dahulu \\
\hline 4 & - Ngasih & - Memberi \\
\hline 5 & - Nengok & - Lihat \\
\hline 6 & - Tengok & - Lihat \\
\hline 7 & - Udah & - Sudah \\
\hline 8 & - Kukasih & - Aku Berikan \\
\hline 9 & - Gak & - Tidak \\
\hline 10 & - Awak & - Saya \\
\hline 11 & - Nanya & - Tanya \\
\hline 12 & - Motormu & - Sepeda Motor \\
\hline 13 & - $\quad$ Aja & - Saja \\
\hline 14 & - Samamu & - Bagimu \\
\hline
\end{tabular}

The factors that influence the lexical variation in the conversation are Function (Informal language) like when the students to say sulit (difficult) they just say payah (the informal youth language to say sulit)

Data 3:

This record was taken place under the leafy trees in the front of the campus. There are five persons who was talking in this situation. They are Anggih, Ediman, Ihsan, Fery, and Dody in the same level of semester in the diffrent group of English department FKIP UHN Pematangsiantar. The conversation was done at 16.00-16.20 pm on Saturday 06 February 2016.

Anggih : Gampangnya speaking. ( The speaking was easy).

Ediman : Dan jangan terlambat. (And don't be late ).

Anggih : Kerapian. ( Tidiness ). Mudah panas itu kan Lae? (Is that easy to get warm,

dude? ). Itu...udah intel itu Lae? (It's...Has it been intel, dude? ) Asus nya

itu? ( Is that Asus?).

Ihsan : Bukan. Advan ini. (No, it's not. This is Advan ).

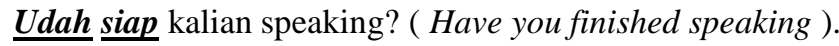

Fery $\quad$ Inilah dia. Video ini. ( This is it. This video ).

Ihsan : Ujian semester nya?, Udah? ( The semester test?, Have you?). 
Menjelaskan per bab kah? ( Explaining each chapter, isn't it? ).

Fery: Ujian speaking kami, buat video. ( Our speaking test was, making a video ).

Tapi, videonya gagal. ( But, the video was failed).

Karena suaranya pelan $\underline{k a l i}$. (Because, the sound was too low ).

Jadi, kami buat lagi lah. ( So, we made it again ).

Dodi: Jadi, kalau videonya gagal lagi? ( So, if the video's failed again? ).

Kayak mana lah itu? ( How about that?).

Fery: Yaudahlah! ( So be it! ).

Ediman : Mati aja lah! ( You're doom!).

Anggih : Bilanglah, inilah usaha kami, Pak! ( We have to say this is all our efforts, Sir! )

Ediman : Mati $\underline{\boldsymbol{a j a}}$ lah! ( Darn you! )

Anggih : Tolonglah hargai usaha kami, Pak! (Please, respect our efforts, Sir! )

Ediman : ( Sambil tertawa) Ya kan Lae,...Mati aja lah! ( (laughing) Right, dude,..Darn

you! (Pigi aja lah ke laut! ( Darn you to the ocean! )

Ihsan : Siapa dosen speaking kalian? ( Who is your speaking lecturer?) Pak David? (

Sir David? ).

Fery: Mam Yanti. ( Mrs.Yanti).

Ihsan: Grup apa? ( What group? ).

Fery: Grup I. ( Group I ).

Ediman : Ibu itu yang ngawas kita ujian kemaren, kurasa... ( She's who has watched us closely yesterday, I think... ).itu nya Mam Yanti? ( Is that Mrs. Yanti? ).

Ihsan: Sir Rudi lah enak. ( Sir Rudi is good).

Ediman : Yang ngawas ujian PP kan. (Who has watched us closely in PP's test).

Ihsan: Sir itu terbuka untuk nilai. (He's open to us about the marks ).

Ediman : Mam Yanti yang ngawas kita ujian PP nya kan? (Is Mrs.Yanti the one who has watched us closely in PP's test? ).

Ihsan: Yang tinggi itu? ( The tall woman ).

Ediman : Mam Yanti tinggi nya, woy? (Is Mrs.Yanti tall, guys? ). Yang satu lagi Mam

Reina ya kan. ( The another one was Mrs.Reina, isn't it? ).

Ihsan: Mam Reina ngajar grammar IV tu. Grammar III - IV. ( Mrs.Reina teaches

grammar IV. Grammar III - IV).

Ediman : Hari itu, keluar Mam itu pas ujian belum siap. (At that day, she went out when the test isn't over yet. ).

Anggih : Itu si Daniel! ( Memanggilnya ) Daniel..! Dan..! ( That's Daniel! (Shouting for

him ) Daniel..! Dan..! ).

Ediman : Oi..! Oi...! Oi...! ( Oi..! Oi...! Oi..!) Datang dia, datang dia.., ( Here he comes,

here he comes.., ). Kita adakan rapat pleno tentang klub kita ini. ( We'll hold a

plenary meeting about the club).

Ihsan: Ada urusan dia mungkin. ( Perhaps, he has got a business).

Udah gabung jadi anggota dia? Belum? ( Has he joined the club as a member

yet? Not Yet? ).

Ediman : Si Winton nya! ( Winton is! ).

Ihsan: Klub itu harus jelas itu nya... ( The club must be clear about the... ).

Ediman : Ini klub baik - baik nya ini, gak ada balap - balap liar. ( This is a good club,

there's no any illegal-wild racings ).

Fery: Pertama kali, pas si Hillson pembinanya, aku..aku gak, aku.. (In the first time,

when Hillson is the builder, I'm..I'm not, I'm... ).

Ediman : Si Winton nya! ( Winton is! ).

( calling for Winton ) Halo, Bang! ( Calling Winton ) Hello, Brother! ).

Datanglah kemari dulu, cepat ya! ( Come here, please. Quick! ).

$\underline{\text { Dah }}$ siap orang itu! ( They have already finished! ). Disini, di DPR! ( Here, on _the *ULT! ).

Ihsan: Dimana kos nya? ( Where is his kost? ).

Ediman : Di 'SS'. Siantar square, Lae. ( In 'SS'. Siantar square, dude. ).

Ihsan: 'SS'? Jalan Pane? ( 'SS'? The Pane street? ).

Ediman : Mungkinlah! ( Maybe! Katanya sih kalau dia mau ke Siantar square, dia jalan aja. ( He said that if he wanted to go to the Siantar square, he just walked to it. ).

Ihsan: Maunya dia ambil kos yang depan kampus aja gitu. ( He should have taken the

kost which is in front of the campus. ).

Ediman : Eh, dah siap video speaking mu? ( Eh, have you finished your speaking video?).

Ihsan: Udah. Tapi, katanya Kamis! Buang-buang waktu pun! ( I have. But, he said 
Thursday! It's been wasting my time. ).

Ediman : Mau datang kemari dia. ( He wants to come here. ).

Lagi dijalan dia sekarang. ( He's on his way now. ).

Daripada si Hillson itu! ( Instead of the Hillson! ).

Heh, mau kemana kau? ( Hey, Where do you going? ).

Anggih : Bentar! Kesana nya, Lae! ( Just a minute! Over there, Buddy! ).

\section{Analysis data 3:}

In the conversation above, we can find 20 Lexical variations they are: udah, siap, kali, kayak, yaudalah, bilangla, aja, lae, pigi, mam, sir, pas, gak, bang, dah, DPR, SS, gitu, siap, and bentar.

The twenty lexical variations used by the students in communication among friends in data 3 clasified into formal and informal lexical variation, they are:

\begin{tabular}{llll}
\hline No & & \multicolumn{1}{c}{ Informal } & \multicolumn{1}{c}{ Formal } \\
\hline 1 & - & Udah & - Sudah \\
2 & - & Siap & - Selesai \\
3 & - & Kali & - Sangat \\
4 & - & Kayak & - Seperti \\
5 & - & Yaudahlah & - Ya sudahlah \\
6 & - & Bilanglah & - Katakan saja \\
7 & - & Aja & - Saja \\
8 & - & Lae & - Saudara Ipar \\
9 & - & Pigi & - Pergi \\
10 & - & Mam & - Ibu \\
11 & - & Sir & - Bapak \\
12 & - & Pas & - Pada saat \\
13 & - & Gak & - Tidak \\
14 & - & Bang & - Abang \\
15 & - & Dah & - Sudah \\
16 & - & DPR & - Dibawah pohon rindang \\
17 & - & SS & - Siantar Square \\
18 & - & Gitu & - Begitu \\
19 & - & Siap & - Selesai \\
20 & - & Bentar & Sebentar \\
\hline
\end{tabular}

The factors that influence the lexical variation in the conversation are Function (Informal language) the students use their style like when the students to say dibawah pohon rindang (under the leavy trees) they just say DPR as the word abbreviation of Dibawah Pohon Rindang (under the leavy trees).

Data 4:

Meri and Siti were talking in the classroom. They are classmate of semester one of English department FKIP UHN Pematangsiantar. The conversation was done at 14.00-14.20 pm on Thursday 04 February 2016.

Meri: (Kau ngapain ?) What are you doing?

Siti: (duduk-duduk $\underline{\underline{a j a}}$ ) Just sit on chair ...

Meri: (kenapa ?)Why?

Siti: (gak papa ) Nothing

Meri: (kalian ada ikut kegiatan ?) Did both of you join an activity or something ?

Siti: (enggak. Kegiatan apa ?) No.... What kind of activity?

Meri: (iya $\underline{\text { entah }}$ apa gitu) Anything

Siti: .(gak ada, inilah tengok) No. We choose nothing, Look at this ( give a brochures )

Meri: (apa itu ?)What's that ?

Siti: (Himpunan Mahasiswa Islam ) HMI

Meri: (sudah,kau?) Yes, I have . How about you ?

Siti: (males) i'm lazy/Not yet.

Meri: (kenapa kau gak ikut) Why don't you join it?

Siti: ( $\underline{\text { males }})$ Too lazy to do it.

Meri: (apa alasanmu) What's your reason?

Siti: aku males kalau yang nginap") I'm so lazy to spend the night for it .. aaaaaa

Meri: (bilanglah) Just say it .

Siti: .(tadi ada yang baca,katanya nginap) 
Lexical Variation on Students' Daily Conversation at Campus by First Year Students of English Department

Someone has just read it . he said it's spend the night

Meri: (apa alasanmu gak datang) What's your reason to not to came?

Siti: (lihat ini! Dari tgl 7-13 pebruari) Look at this! From $7^{\text {th }}-13^{\text {th }}$ on February

Meri: (jadi)So ?

Siti: (kau nginap) Do you spend the night?

Meri: (oh sorry lah ya.......bagusan aku dirumah makan tidur) Oh! I'm sorry. Its better for me

to stay on may house for eating or sleeping

Meri: (menurut mu kayak mana itu) What is your opinion about that ?

Siti: (dan gak di pungut biaya ya.gratis) It wiil not collect any expence, that's free

Meri: (gratisnya! kenapa gak ikut) Its free ! Why don't you join ?

Siti : (aaaaaa....mau makan apa awak, mau makan batu) Aaaa...aaaaa... What should we

eat? would we eat stone?

Meri: (tapi kayaknya ada yang membiayai) But they said someone will pay it .

Siti: (siapa?siapa yang bayar) Who ? Who will pay?

Meri: (HMI itu kayak mana) What is HMI exactly?

Siti: ( shows the HMI brochures )

Meri: (kau dapat dari mana ini) where do you get it from ?

Siti: (gak tau) I don't know

Meri: (bagaimana ujian agama tadi) How about religion exam ?

Siti: (Alhamdulillah.bisalah) Alhamdulillah . Not bad

Meri: (ada yang payah tadi) Is there something difficult with it?

Siti: (aliran itu kan) About ideology, right?

Meri: (kau bisa tadi) Did you get it ?

Siti: (ntah apalah yang kubuat situ) I don't now what things I white.

Meri: (aliran apa aja tadi kau buat) What ideology, did you write ?

Siti: ?(kau $\underline{\boldsymbol{u d a h}}$ ditanya,aliran itu apa?aliran mutazila itu aliran apa,aliran alhassunah

waljamaah itu apa) Its totally asked, what is ideology, Mutazila ideology, what is

that, what is alhussanah wal jamaah

Meri: (mendingan soal tahun ini apa tahun lalu?) Which one is easier ? this years questions or

last years questions ?

Siti: (tahun lalu) Last year

Meri: (gampang) Is it easy?

Siti: (gampang) Easy

Meri: (tahun ini) How this year ?

Siti: (gampang" susah gitulah) Its not bad.

\section{Analysis data 4:}

In the conversation above, we can find 14 Lexical variations they are: ngapain, aja, nggak, entah, gitu, tengok, males, sori, kayak, awak, payah, ntah, udah, and gampang.

The fifteen lexical variation used by the students in communication among friends in data 4 clasified into formal and informal lexical variation, they are:

\begin{tabular}{|c|c|c|}
\hline No & Informal & Formal \\
\hline 1 & - Ngapain & - Sedang Melakukan apa \\
\hline 2 & $-\mathrm{Aja}$ & - Saja \\
\hline 3 & - Gak & - Tidak \\
\hline 4 & - Enggak & - Tidak \\
\hline 5 & - Entah & - Tidak tahu \\
\hline 6 & - Gitu & - Begitu \\
\hline 7 & - Tengok & - Lihat \\
\hline 8 & - Males & - Malas \\
\hline 9 & - Sorry & - Maaf \\
\hline 10 & - Kayak & - Seperti \\
\hline 11 & - Awak & - Saya \\
\hline 12 & - Payah & - Sulit \\
\hline 13 & - Ntah & - Tidak tahu \\
\hline 14 & - Udah & - Sudah \\
\hline 15 & - Gampang & - Mudah \\
\hline
\end{tabular}


The factors that influence the lexical variation in the conversation are Function (Informal language) like when the students to say sedang melakukan apa (what are you doing) they just say ngapain (the informal youth language or style to say what are you doing).

\subsection{Research Findings}

The data which have been analyzed in lexical variation as found in the communication among friends have been collected and counted and included with the factors that influence the lexical variation. The lexical variations are found by the writer after analyzing the data, such as:

1. The first year students of English Department FKIP Universitas HKBP Nommensen Pematangsiantar used many lexical variation in their daily conversation at campus

2. The factor do influance the students' lexical variation is the language function of the students namely informal lexical variation.

3. The informal lexical variation can be happen because of the style of speaking that used by the students.

\subsection{Discussion}

This research aims to find out the lexical variation in communication among friend on the first year students of English Department FKIP Universitas HKBP Nommensen Pematangsiantar. The writer analyzes what lexical variations are commonly used by the students and what the factor influences it. To answer the questions, the theories used are (Wardhaugh, 1972:194) stated about the factor do influence the lexical variation based on (Wardaugh, 1972:189). According to Wardaugh (Wardaugh, 1972:194), Lexical variation is the difference in sound and structure of a particular language across setting.

The factor do influence the lexical variation (Wardhaugh, 1972:189), they are: By age, is one kind of linguistic phoneme we can study and about which we can ask a variety of linguistic, psycholinguistic, and social linguistic. By sex or Occupation, here are meant as the kinds of jobs which people own; occupation will influence the way of people to speak whereas sex the way of the man and women in conversation. Social status, will also speak differently because social status includes economic, education, and ethnic. By function, there are both formal and informal styles of speaking and writing. Regional variation, May influences people way to communicate.

Based on those definitions and factors influence, the data prove that there are many lexical variations used by the first year students of English Department FKIP Universitas HKBP Nommensen Pematangsiantar. There are seventy four lexical variation using informal language function that is spoken by the students in their daily campus conversation. The lexical variation was influenced by function, there are both formal and informal styles of speaking.

\subsection{Conclusion}

\section{CONCLUSION AND SUGGESTIONS}

Based on all disscussion, the researcher concludes that in daily communication at campus, first year students of English Department FKIP Universitas HKBP Nommensen Pematangsiantar usually used informal language function, it can be seen from the way of the students when they want to say something to their friends often use word abbreviation like to say "ya sudahlah (formal version) become ya udalah (informal version by word abbreviation) and slang language style.

\subsection{Suggestions}

Suggestion is the phychological process by which one personguides the thought, feeling or behavior of another. In daily conversation at campus, the students usually use informal lexical variation as the fact showed above. The writer believe that the habist of using informal lexiacal variation will give negative effect when they are on formal speaking situation. So, to avoid it, the writer give some suggestion, such as:,

1. The lecturer should teach the students by using formal language that would stimulate and habits the students to respon by using formal language and it will become a habits and even a culture for the students to speak.

2. The lecturer should encourage the students to take more activities that can enrich the students vocabularies, can used formal language when their communication, and also encourage the students to write their diary, so they can develop their vocabularies and used formal language.

3. In daily teaching learning process, the students must have high motivation to improve their vocabulary in formal fuction.

4. In daily campus conversation, the students habit them selves to speak formally. It can train them to be usual with formal language 


\section{ACKNOWLEDGEMENT}

The writer would like to thank to his colleague, Herman (fukadaherman@gmail.com) who help to provide assistance and to edit this article, so this research can be resolved.

\section{REFERENCES}

[1] Anttila, A. (2000). Variation and phonological theory. Boston University/National University of Singapore.

[2] Arikunto, S. (2006) Procedure Penelitian Suatu Pendekatan Praktik, Jakarta: Rineke Cipta.

[3] Bayle, R. (2001). Sociolinguistic variation in American sign language, Washington D.C: Gallaudet University Press.

[4] Brown, H. D. (1994). Teaching by principles: An interactive approuch to language pedagogy. San Fransisco: San Fransisco University Press.

[5] Fishman, J. A. (1971). Language at the social, Massachhusett, New House Publisher.

[6] Fishman, J. A. (1972). Bilingual sequence at the social level, Massachhusett,New House Publisher.

[7] Hornby, AS. (1975). Oxford advanced learner's dictionory of current English, Oxford: Oxford University Press.

[8] Hudson, R.A. (1985). Sociolinguistics, London and New York: Cimbridge University Press.

[9] Hymes, D. (1974). Foundations of sociolinguistics: An ethnographic approach. Philadelphia: University of Pennsylvania Press.

[10] Katomihardjo, S. (1988). Bahasa cermin kehidupan masyarakat.

[11] Lado, R. (1964). Language teaching: A scientific approach, New York: McGraw Hill,Inc.

[12] Nababan, P. W. (1986). Sociolinguistic suatu pengantar, Jakarta: Gramedia Pustaka Umum.

[13] Radford, A. (2009). Linguistics-An introduction, New York: Cambridge University Press.

[14] Sapir, E. (1971). Language (An introduction to the study of speech). Harcourt Brace.Javanovich. Inc. Strauss, A., \& Corbin, J. (1990). Basics of qualitative research: Grounded theory procedures and techniques. Newbury Park, CA: Sage Publications, Inc.

[15] Wardaugh, R. (1972). An introduction to sociolinguistic, London: Page BROOS. 